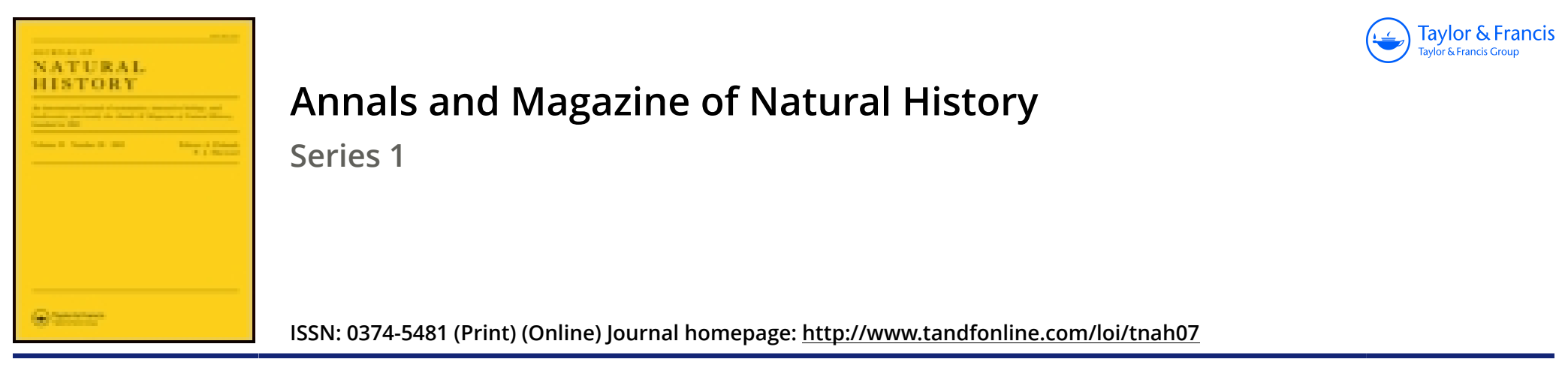

\title{
XVI.-Considerations on the tribe of the Podaxineæ, and description of the new genus Gyrophragmium
}

\section{Montagne}

To cite this article: M. Montagne (1843) XVI._Considerations on the tribe of the Podaxineæ, and description of the new genus Gyrophragmium, Annals and Magazine of Natural History, 12:75, 111-113, DOI: 10.1080/03745484309442497

To link to this article: http://dx.doi.org/10.1080/03745484309442497

曲 Published online: 04 Dec 2009.

Submit your article to this journal $₫$ 
As this is the only species with which I am acquainted of a green colour in its growing state, I was at first inclined to consider it the Fragilaria conferroidles of Greville; but I have lately reccired from MIr. IIarrey nn authentic specimen of that plant, which I lave nscertained to be Fragilaria hycmalis, Lyngb.

Ehrenbero deseribes his Frag. pectinalis as striated. I have nerer succeded in detecting the slightest nppearance of stria on the lateral surfaces, althongh I have repeatedly and carcfully exanincel them; nor did MIr. Berkelcy, to whom I sent specinens, perceire them. On the other hand, Mr. Dalrymple observes, that the strix, though difficult to sce, are nevertheless present. Mr. Jenner, who is a very aceurate olsecrver, thinks that there are very faint, ahnost obsolete strix, which en be only secn when the endochrome is removed: in another letter, howerer, he enumerates the absence of strix among the character's of the species. Thus it will be secn, that eren if strix are present in this plant, they cannot be adopted as one of its characters without the risk of mislcading the observer.

Plate II. fig. 6 . a, states of $F$. virescens; $b$, frustules, deprived of their endochrome; $c$, lateral view.

Analysis.

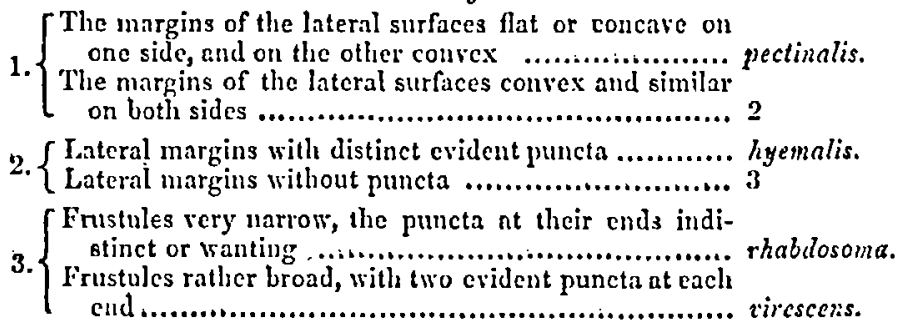

[To be continued.]

XVI.-Considerations on the tribe of the Podaxince, and description of the new genus Gyrophragmium. By M. Most.laxe*.

Ayoxgse the Trichogastrous Fungi there is a suall tribe which has recently been raised to the rank of a family by $\mathrm{AI}$. Corda, and which is remarlable among other charncters by the presence of a columella traversing the axis of the peridium : it is the lodaxinea. This tribe, which was formerly composed of the three gencra $C y$ clodcmn, Klotzsch, Cauloglossum, Greville, and Podaxon, Desraux, became all at once doubled by the addition of threc others, the Secotium, Kunze, the Polyplocium, Berkeley, and the Gyrophragmium, nob., which forms the principal object of this notice.

* From an extract by the Authorin the 'Comptes Rendus,' No. 16, 1813. 
Gyrophragmium results from the dismembering of the genus Montagnea, founded by Fries, 'Genera Hymenomycetum,' p. 7, on two fungi which grow on the shores of Maguclone, in the environs of MIontpelier, one of which had received the name of Agaricus arenarius from M. DeCandolle, the other that of Agaricus ocreatus from M. Delile. The continued study which I have made of the second of these species, subsequently found near Bona and brought in all stages of crolution by Captain Duricu, Member of the African Commission, has proved to me that these two fungi, although similar and apparently related, do not belong to the samc family. A very young individual of Gyroplragmium Dunalii showed indeed in the clearest manner, that what had been taken for the pileus of an Agaric was the superior half of a peridium, the inferior half of which is represented by an ample colva surrounding the stem, and that the supposed leaflets or lamclln were only processes, or rather partitions cmanating from all the points of the pileiform portion of the peridium. The following are the characters upon which this curions genus is established :-

Receptaculum stipatum. Peridium primo turbinatum, dein medio orbiculatim ruptum superne pileiforme cum stipite centrali ad apicem usque producto, volva ampla (quae nihil aliud nisi pars peridii inferior) instructo continuum. Capillitium in dissepimenta contextum lamelliformia subparallela $\mathrm{c}$ peridii toto hemisphærio descendentia, a stipite distantia, in plano ramosa, non autem anastomosantia, sinuosa, plicato-crispata adeoque densata ut sibi cohærere videantur, primo lenta oliracea, tandem exarescentia fragilissima, nigra, subtus libera, labyrinthiformia. Flocci liberi nulli. Spora globosæ, pedicellatx, dissepimentis affixa. Contextus peridii stipitisque fibrosus in dissepimenta continuatus. Fungi arescentes, persistentes, habitu Agarico vel Boleto similes, specie volvati aut annulati, stipitati, in arenosis maritimis Africa borealis et Gallia australis hucusque obvii.

The genus Gyrophragmium differs from Polyplocium, Berk., on the one hand by the form and the rigidity of its partitions, and on the other by the absence of free filaments intermixed with the sporules, filaments which are found in the latter genus. Just as in Secotium its sporules are fixed by a short pedicel to the walls of the compartments, but thesc compartnents, which are frec in $G y-$ rophragmizm, form a spongy tissue in the other genus by their frequent anastomoses.

Considered according to the degree of their structure, the genera of the tribe Podaxinece may be arranged as follows: Cauloglossum, Cycloderma, Podaxon, Secotium, Polyplocium and Gyropluragmium. As Secotium is the form of transition from Podaxon to Polyplocium, so the latter evidently constitutes a passage between the first of thesc gencra and Gyrophragmium. I have 
every reason to suppose that one day, when we are better acquainted with the history of its derclopment, of uhich we are entirely ignorant at present, the genus $*$ Monlagnea itself will have to be placed at the head of this tribe, from which Batarea is probably not so far remored as is supposed.

\section{XVII.-On the different modes of preserving Microscopic Objects.} By John W.r. GrifFith, M.D., F.L.S. \&c.

Durixa the progress of microscopic experiments and examinations, we are continually meeting with parts in which some pecuilar structure is particularly well illustrated, which we are anxious to preserve; sometimes, for the purpose of reference and comparison, we are obliged to keep specimens of different structures by us. It is my intention here to say a few words on the best methods of so doing.

The description of these is no slight task, for it is by no means easy' to render a clear account of the manipulations required, so as to make them applicalle by others; moreover, one in the habit of continually putting up specimens is apt to overlook mentioning certain minutia, which, from use, he is hardly aware of performing, but which are cssential to the perfection of the work. The main point is to protect the object from injury by surrounding influences, such as violence, the action of the preservative liquids, evaporation, \&c. This in a few cases is impossible, but in the majority any alterations produced in those specimens which are properly put up are so slight as not to destroy their value. There are two modes of viewing microscopic objects ; one when illuminated by reflected, the other by transmitted light. I shall first notice the former.

OPAKE OBJECTS are of two kinds; those preserved in the dry, and those in the moist state. o. The dry ones are usually fastened upon circular discs, or columns of cork, by a little gum, or solution of gum mixed with isinglass; they are then transfixed with fine pins, so as to be stuck into cork, which forms the bottom of the drawer in which they are arranged. Sometimes the circular flat discs of cork are fastened upon glass slips, and arranged in cabinets in the same manner as transparent objects. 'The cork must always be blackened, so as to prevent the reflection of any luminous rays which might interfere with the distinct vision of the object. 'This is effected in cork either by scorching or painting it over with an intimate mixture of fincly powdered lamp-black and gum-water. But almost any black surfaces may be used for this purpose-black velvet, silk, paper, or blackened metal. When the opalie object is

- M. Montagne has very lately reccived valuable information on this genus from M. Dunal, which he will no doubt shortly publish. From the observations of Dunal, it appears that all the specimens hitherto collectel have been imperfect. We are liappy to hear that $M$. Dunal, whose letter and sketches we have had the advantage of iuspecting, is using every exertion to procure this most curious and interesting production in every stage of growith.-ED.

Ann.\&.Mag. N. Hist. Vol. xii. 